\title{
The Realistic Genre and its Development in World Literature
}

\author{
Sobirova Zarnigor
}

\begin{abstract}
Realism is a way of expressing life through images in accordance with real events and events. Realism strives to embrace reality with all its contradictions, given the literature itself and its role as a means of knowing the outside world, giving the writer the opportunity to reflect on all aspects of life. In the literature based on the method of realism, the principle of describing reality is a priority. Consequently, the literature of Realism is the highest stage in the development of world literature. Realism (Latin realis - material, real) is a philosophical direction. According to him, the reality outside the consciousness consists of the existence of ideal objects (Plato, medieval scholasticism) or objects of cognition, which are not related to the subject matter, process or experience.Realism and realistic features of the world literature is on the point of the article to be discussed about.
\end{abstract}

Keywords : Realism, realistic features, principle, cognition, antico-realism, realism of the Renaissance, enlightenment realism and social realism.

\section{INTRODUCTION}

In literature, realism is a way of expressing life through images in accordance with real events and events. Realism strives to embrace reality with all its contradictions, given the literature itself and its role as a means of knowing the outside world, giving the writer the opportunity to reflect on all aspects of life. In the literature based on the method of realism, the principle of describing reality is a priority. Consequently, the literature of Realism is the highest stage in the development of world literature. Realism (Latin realis material, real) is a philosophical direction. According to him, the reality outside the consciousness consists of the existence of ideal objects (Plato, medieval scholasticism) or objects of cognition, which are not related to the subject matter, process or experience. Realism is also characteristic of Homer and Dante, Shakespeare and Rasin, Firdavsi and Navoi, because their vitality and sincerity are expressed in the works of these classical artists. But realism, as a literary method or literary direction, requires that the writer consistently adhere to the principle of living and true reflection of reality, and consciously study the human and the outside world. In this sense, world literature has only reached a new phase of its development in the 19th century, based on the method of realism.

Revised Manuscript Received on October 15, 2019.

* Correspondence Author

Sobirova Zarnigor *, A teacher of Foreign Languages Faculty, Bukhara State University, Uzbekistan

\section{LITERATURE REVIEW}

Rastinyak, Julien, Sorel, Nicholas, Nikklti, Rebecca Sharp, and many others operate in simple, simple ways. The combination of these characters shows that they do not move away from life and complex circumstances.

\section{METHODS AND ANALYSIS}

There are different views on the timing of realism as a method. Some researchers have argued that realistic methods of describing life have been around since ancient times, and that these methods have gone through various stages, including the concepts of antico-realism, realism of the Renaissance, enlightenment realism and social realism. According to other researchers, realism emerged as a creative method at the same time as the creation of family and domestic novels in the 18th century. The idea that realism began to develop in European literature in the 1930s has been widely accepted by many literary critics, as evidenced by the fact that the principle of a true depiction of reality in European literature is widely and deeply expressed in the high social and analytical forms. Belinsky says that beauty in art is present in life, and that the expression of beauty is a prerequisite for artistic integrity. This definition covers several features of realism. First, the portrayal of life in realism is not a copy of life, but a "creative" way of understanding the meaning of life events and selecting the facts that best convey this meaning. Secondly, this choice creates a necessary "texture" of creativity. The creator must be able to think clearly about the meaning of facts, and at the same time, to match the facts, which are very similar to them. According to Belinsky, the development of higher realism in literature could be achieved only by turning away from reality and, first and foremost, portraying the lives of the masses and ordinary people. Thus, honesty and artistic sensitivity are two important requirements of realism. In order to make a true and effective portrayal of life, it needs to be comprehensive and comprehensive. To do this, you must show life with all its contradictions. Therefore, a straightforward description of life's conflicts is one of the main requirements of realism literature. Each creative method is based on a particular social context and summarizes the aesthetic ideals of a particular social class in society.

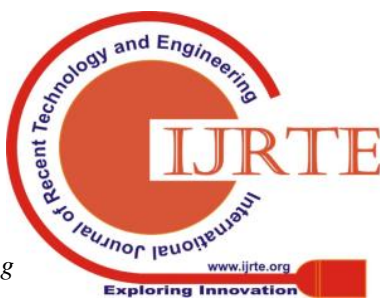


The method is a set of general principles of artistic reflection of reality. Take, for example, the principles of the method of realism. Realism is the first to take the subject and the material directly from life, secondly to summarize the character of a particular social class in each image; Requires.

These principles are common principles for all artists who use realism. Professor Izzat Sultan, a well-known literary scholar, comments on realism: "The true understanding of reality and its true perception of artistic images in all its contradictions is called realism." The personality of the artist and his socio-aesthetic ideology play a very important role in realism. Surrealism has become a symbol of the struggle for the best of humanity, the struggle to achieve a genuine life for all people around the world. That is why the works of great realist writers were inspired by a consistent national spirit. In the first half of the nineteenth century, there was no clear boundary between romance and Realism, with O. Balzac ("Slippery Leather"), G. Stendal ("Palm Temple"), V. Hugo, and Ch. Dickens' work is brilliant. At the same time, romantic motives have long been in the artistic fabric of realistic works. In the middle of the 19th century, with the departure of European literature from the traditions of romance, a new era in the formation of realism as a method began. In the late 19th and early 20th centuries, English literature coincides with the period of critical realism. To the artists of this period Ch. Dickens, U.M. Thackeray, E. Gaskell, R. Browning. In these writings, themes such as romance, real life, and hope for the future are intertwined and attract any reader. It is not an exaggeration to say that late 19th and early 20th centuries English literature experienced the most prosperous period in its development. This period has been included in the pages of world literature with works that are rich in life, cultural and spiritual, historical and philosophical views. This progress, which had just begun in the development of science, grew very rapidly and included the aspirations and aspirations of the human race. In the literature, the era of realism is very close to life, connected with the wide development of literary and novel types such as new stories, novels and drama. Realism requires copying life rather than passing it through the "sieve" of thought. The work of realism reveals the inner meaning of life events. To do this, the realist writer uses the methods of characterization and individualization, that is, the inner meaning of the events underlying life, and the meaning is expressed in a lively form, "life-like".

In the work of realism, life is manifested in the eyes of the reader in the form of a reliable picture of certain individuals, images and characters. According to scholars describing realism, realism "... in addition to the truthfulness of the details, it also requires a true depiction of the characteristic features in the typical environment." "Literature is the expression of society," Balzac said. This fact is now the most accurate, the result of a mind-boggling study of the history and poetry of the people. Realism means different situations, different characters in clear details. "Genre of Realism also requires writers to portray images as they are, as well as the whole situation. He asks for backwardness and justification for the socio-historical lines, based on this fact. The

romanticism of simple characters and characters in their own way, Ch. Harold, Cote Moore, Clot Florro, Lantenok, Simurden and others have expressed romance in their novels. Whereas, the method of simplicity of romance differs from that of the realists. The creators of romance, while drawing their own image, deliberately distort their imagination from history and living conditions, thus trying to maintain a realistic, dialectical relationship with real, real relationships. In doing so, they turn their heroes into fairy tales and fantasy environments, using allegorical and symbolic characters. (Manfred, Caine, Prometheus). Realists are fundamentally different, in order to portray ordinary heroes, they try to preserve their original home environment and maintain their vital connection to the development of reality.

\section{ANALYSIS}

The winning of the realistic method is a vivid portrayal of the characters' character, historical portrayal, and the observation of its "rise and fall."

In this way we can see that the plots and structure of realistic works are related to particular characters. Realists have no concept of covering up romantic situations and criminal events. The development of action in the Balzac novels, deeply depicting the objective reality of the fate of one or another hero, amazes the reader with his vigilant logic.

The great writers of France, England and other countries Stendal, Balzac, Dickens, Tewkker, Brentel began to write bright novels. The great realists of the 19th century A. Gorky penciled against the bourgeoisie. The period of Victorian literature, considered to be a positive period in the history of England, is a complex phenomenon of Christian culture, primarily concerned with politics and philosophy. Even the concept of 'manifesto' is changing in European culture. The more the arts go beyond the norm that ensures the freedom and liberty of the artist, the more he presses his views on society, humanity, and the arts. The word starter genre also maintains the boundaries of the manifesto, but they are still not multi-disciplinary and relies on concrete artifacts. For example: Dickens' Oliver Twist and Vanity Fair by U. Teckere are a prime example of this. The multinational specificity of any literature is determined by the nature of theoretic documentation. From this, English literature, with its satirical traditions, uses the genre of essay and the parody genre. In the nineteenth century, political discourse became more common in English novels, and political and economic terms began to appear in the works of Byron and other romantic genre writers, and true philosophy and utilitarianism took a special place in Dickens' writings. In the English literature, the main focus of the 30 s and 40 s is critical realism. Its beginning is marked by the rise of chartists in their 40s. At this time, Ch. Dickens's "Dombie and Son", Tecker's "Fairness of Honor", Sh. The works of Bronte's "Jane Eyre" and M. Gaskel's "Mary Barton" have come to the world. 
During these years, the Teckerei became famous realist writers, poets and critics like the Brontës. Poetry and prose are reflected in the mood of the masses and their opposition to social injustice. Critical realism includes cultural achievements of the past century, illumination of realism, and achievement of art. At the same time, its development is related to the emergence of new aesthetics, new principles in the description of reality and reality. Thus, in the nineteenth century, and especially in the second part of it, realism in the meaning of the creative method of literature of European nations was formed. In the literature of earlier times, the characteristics developed in the literature of realism have reached a high level and have become the main principles of literature. Humanism has become the flag of humanism and realism. Literature has now moved on to study real life and the realities of life. Discovering the conflict between man and the existing bourgeois order is one of the greatest achievements of realism and a contribution to the development of social consciousness. Understanding this contradiction has led to the literature on the need to create a society that meets the characteristics and needs of the existing bourgeois society.

Real scientists give different explanations. The description of the literary scholar B.Suchkov is the most complete. He goes on to state that realism is merely a product of certain historical conditions: "Realism as a creative method is a historical phenomenon that occurred at a certain stage in the development of human cognition; when there is an inevitable need for them to comprehend the essence and direction of the movement of the people, first and foremost, then consciously, their actions and feelings are not the result of passion or divine will, but rather for real reasons, namely, for material reasons. appeared when he began to understand his appointments. In the arts, the method of realism emerged when civil society members were tasked with understanding the forces that undermine social relations, but which are not hidden from direct observation. "Critical realists address huge social issues. These problems reflect the students' perceptions of bourgeois order and inhumanity. Dickens, Teckere, Bronte, and Gaskel, who are not advocates of revolutionary methods of struggle, advocate humanism and democracy.

The works of Jane Eyre (1847), "Sherley" (1849), "The Town" (1853), and "The Teacher" (1847) were among the works of Charlotte Bronte and brought popularity to the Bronte. His work is known as "Jane Eyre." This work put the name of the Bronte in line with the great 19th-century realist writers. The Bronte's works draw public attention by highlighting social equality and explaining women's equality in a literary way. The Bronte heroes have strong moral principles, powered by strong emotions, courage, and courage.

\section{DISCUSSION}

Literature is a precious treasure that helps people learn, innovate and discover themselves. So let's not take any century, there are artists who reflect their time and entertain the reader. The end of the 19th and the beginning of the twentieth centuries is a very historically peculiar period, reflecting the time when capitalism became imperialism. English literature at that time was divided into many streams, groups, and had its own peculiarities, and was reflected in the works and regulations that were created at that time. The influx of groups and groups, the attempts of some poets and writers to intervene in the politics of the country, the emergence of talented young artists, the highlighting of new, previously banned themes in their works, in response to a vibrant and controversial response by readers - all these were the main features of English literature of that time. Realists have also changed their interpretation of human character. In romance, human nature is taken as a separate subjective basis, and in realistic works, it is always the combination of the grandeur and clarity of historical development. That is why it is reflected in the characteristics of nature, the way it is. In the 1840s and 1940s, the genre of realism was born not only in relayism, but also in the English literature. At the same time, the writers began to look at us critically, rather than to represent the world around us. The disadvantages and disadvantages of nineteenth-century England were reflected in the works, one by one, and began to be highly appreciated by book lovers.

Critical realism is an artistic method, a manifestation of realism, developed in world literature and art in the 1930s and 1930s. It was created by the representatives of classical literature in order to continue and renew the best traditions of the most advanced literature of the past, against the outdated and outdated methods of its time. Discovering the social historical roots of these phenomena in the artistic inclusion of life events is the ultimate goal of critical realism. Critical realism requires the writer to critically reflect on the social foundations of life that limit, oppress, disrupt, and bring about moral crises. In the literature and art of critical realism, the principle of historicity is reflected in the depiction of life events, human characters, and the conditions surrounding them as important events, character, and conditions for a given period. Whether the characters in critical realism are "superfluous", "fathers" and "children" or supporters of news and old-fashionedness are the product of their time. However, the historical movement, the process of social development, is interpreted in many works of critical realism as a result of the subjective activities of people. Therefore, only the spiritual world, the beliefs and the beliefs of the people in these works serve as the source of good (good) inspiration in them. Critical realism does not show the road to a happy and enlightened life, but rather reflects the challenges, disadvantages, and conditions that people face in their pursuit of life. This is why this method of fiction is called Critical Realism.

Russian literary criticism has been associated with the emergence of a revolutionary movement for the formation of critical realism, and has interpreted this artistic method as 
writers who consciously fought against capitalism. Representatives of critical realism have intended to show the public through the artistic portrayal of social injustice and moral degradation in the lives of certain individuals and to treat society in this way. Representatives of critical realism in Western Europe, such as Balzac, Dickens, Tecker, Flober, are far from the idea of revolutionary change of reality. Therefore, the portrayal of some of the defects and defects of their work has not been brought forth to expose an unfair society, as Russian literary criticism suggests. Two principles are reflected in works of the genre of critical realism in the 20th century. The first is to describe people's daily lives, their aspirations for a happy life. From the writings of such writers as Remark, Steinbeck, and the films of famous Italian filmmakers such as Fellini and Antonioni, it is impossible to improve human life and change destiny. The second is the artistic perception of the people's liberation movements, including the revolutionary movements of the 20th century, and, therefore, the prospect of social progress. This second principle prevails in some writings by writers such as Rollan, London, Draiser, and the same principle brings their creativity closer to social realism.

\section{CONCLUSION}

In the 19th century, the birth of great works not only in England but also in the development of world literature was the real genre. In addition to the information about realism and critical realism, as well as the works of writers who contributed to the development of realism in the nineteenth century, the role of Charles Dickens and William Tecker in world literature was also discussed. In the 19th century, readers' departure from romance led to the emergence of a real, so-called genre. At this time, people wanted to see the truth, without any paints. This is the reason why writers who started to work in the real-life genre gradually began to take over the world. Particularly in the English literature the nineteenth century is regarded as a critical period. In spite of the hardships and sufferings of the people, the people sought for the good. Topical issues of the nineteenth century, such as respect for human rights, child labor, and the fight against injustice, were often written on paper, and the emergence of new heroes. It also cites examples of works by Charlotte Bronte, Jack London, Charles Dickens, William Tecker, and lists the similarities and similarities of novel characters.

\section{REFERENCES}

1. Abdullajanov Akmalhon. World literature (Text of the report), Namangan, 2015, -88 p.

2. Allamberganov H., Text of lectures in "Foreign Literature", Nukus, 2011, $-42 \mathrm{p}$

3. BoynazarovF., Textbook of World Literature, -T. 2006. -77 p

4. ErgashevaY. A., Text of lectures in "Cultural Studies", Karshi, 2015, -43 $\mathrm{p}$

5. Normatova, World Literature Textbook, -T. 2008. -46 pp

6. Sultan Izzat. Literature theory. Instructor of Tashkent, $1980.365 \mathrm{p}$

7. Boboev T. Introduction to literary studies. T $: \therefore 1980$.

8. Vipper Yu.B. Istoriya vsemirnoy literatury. - M.: Nauka, 1983. -S.163

9. Genieva Yekaterina - Dickens and Thackerey.Russian Magazine: Newsfeed of Europe, 2004 №12

10. DickensCharles. A Tale of Two Cities. -L.: - Scholastic Book Services. 1965. $-76 \mathrm{p}$

11. DickensCh. Great Expectations. -L. 1867
12. Thackeray William. The Yellowplush Papers. - L. 1837 